Environment Conservation Journal 15(3) 81-83, 2014

ISSN 0972-3099 (Print) 2278-5124 (Online)

Abstracted and Indexed

\title{
Impact of light and dark exposure on life cycle duration (days) of Eri silk worm, Philosamia ricini L (Saturniidae: Lepidoptera)
}

\author{
UlkaYadav $\bowtie$, Neeta Jadhav
}

Received:15.04.2014

Revised: 21.06.2014

Accepted:03.07.2014

\begin{abstract}
The impact of dark and light exposure on life cycle duration (days) were studied on Eri silk worm (Philosamia ricini) at Zoology Department Govt. P.G. Madhav Science College Ujjain. The diseases free laying (DFL's) were collected from Govt. Sericulture Dept. Indore. Worms were reared under hygienic laboratory conditions. The optimum $25 \pm 2^{\circ} \mathrm{C}$ temperature and $75 \pm 5 \%$ Relative humidity were maintained during complete in control, dark (24 hours) and complete light (24hours) condition. The duration of life cycle of the larvae reared in dark was significantly better than the larvae kept in light condition.
\end{abstract}

Keywords: Dark, exposure, life cycle, light, Philosami aricini

\section{Introduction}

The reduction of rural poverty continues is to be a paramount goal of the developing countries like India, so far various strategies (sericulture is most appropriate out of them) have been pursued to address this concern and rural employment creation is one of the major aspects. The global scenario clearly indicates the enormous opportunities for the Indian silk industry, because India is the second largest producer of silk in the world, it has the unique distinction of being only country producing all the five commercially traded varieties of natural silks namely Mulberry, Eri, Muga, Tropical Tasar and Temperate Tasar also it has distinct advantage of practicing sericulture all throughout year, yielding a stream of about 4-6 crops as a result of its tropical climate. Silk is mostly used in manufacturing of cloth. It is also used in making of surgical sutures, tire lining, oil protein and artificial vitamins. Waste material of $B$. mori is used as an artificial diet for animals and as green manure for crops (Ishfaq and Ikram, 1999). The main activity of natural silk production is practiced around the irrigated forest plantation of Changa Manga, Kamalia, and Multan in Punjab province (Anonymous, 1990). Different species of Mulberry may have compotional differences and might lead

\section{Author's Address}

Department of Zoology, Govt. P.G. Madhav Science College, Ujjain (M.P.)

E-mail:ulka.yadav@gmail.com to vary effects on $B$. mori growth and silk production (Mahmood et al., 1987). Fukada (1960) reported that about $70 \%$ of silk protein produced by the $B$. mori is directly derived from the protein contents of mulberry leaves. Sericulture involves rearing of silk worm and production of silk. Silk is highly valued natural textile fiber of animal origin. No other fabric has fascinated man over millennia as silk. Silk obtained from sources other than mulberry are termed as Non Mulberry or Vanya silk (Eri, Muga, Tropical Tasar and Temperate Tasar). Eri silk is known as Non Violence or Ahinsa Silk (there is no need to kill the pupae inside the cocoon as in the case of other silk because the Eri silk is spun into thread like cotton). Monks in India prefer this silk due to non-violence silk.It is also said to be Poor person's silk because its cost of production is very less than other silk.The Eri silk is so popular because of following qualities:- Texture of the Eri fabric is coarse, fine and dense, it thermal property, soft texture and moisture absorbent qualities. Eri silk is more durable and strong hence it is widely used in home furnishing. Eri silk is produced by Eri silkworm Philosami aricini feed on caster (Ricinus commumis) leaves. The main focus of present study is on socio-economic development of rearesof Eri silk worm because Eri culture provides following opportunity to rearers:- 
1. High employment potential.

2. Low gestations, High returns.

3. Women friendly occupation.

4. Ideal program for weaker section of society.

5. Eco friendly activity.

6. Satisfies equally concern.

In the present study, some experiments were carried to determine the effect of light and dark exposure on life cycle duration (days) of Eri silkworm (Philosami aricini) to improve the productivity and profitability.This study may be further useful to those who are eager to contribute to the sustainable development of rural India through Ericulture.

\section{Material and Methods}

The present study conducted in the Zoology Department of Govt. P.G. Madhav Science College Ujjain, (M.P.). Department runs Sericulture (Applied animal science) as a special paper for post graduate course. Department has a well established and equipped Sericulture Lab and well maintained Mulberry and Caster garden for nourishment of Mulberry and Eri silkworm.Disease free lying (DFL's) of Eri silk worm (Philosami aricini) were collected from Govt. Sericulture Dept. Indore (M.P.) Rearing was done in the prevailing climatic condition and standard tray rearing method was adopted as recommended by Choudhary et al., (1982). The aim was to observe the differences in the Philosami aricini life cycle duration under complete light and dark condition. In the experiment, Philosami aricin $i$ was reared under laboratory conditions of optimum $25 \pm 2^{\circ} \mathrm{C}$ temperature and $75 \pm 5 \%$ Relative humidity up to adult stage.There were three experimental units (control, light and dark), with 5 replications the experiments were laid out in a Completely Randomized Design (CRD).The rearing room and equipments were cleaned, washed thoroughly and properly disinfected with $2 \%$ formalin (by using a sprayer) before rearing. Rearing was carried out under hygienic conditions of feeding, cleaning, spacing and sanitation as followed by Krishnaswami et al., (1973). The eggs were incubated at temperature of $25 \pm 2{ }^{\circ} \mathrm{C}$ and $\mathrm{RH}$ $75 \pm 5 \%$ with 18 hours. The temperature and $\mathrm{RH}$ was manually controlled inside the rearing room at the desired levels. Larvae of Iinstars were selected from the bulk and placed in three trays. First batch reared with control (normal light condition), second having no light for 24 hours (complete dark condition) and third with light for 24 hours (complete light condition).The Eri silk worm larvae were fed caster leaves twice during Iinstars, thrice during II and III instars and four times during IV and $\mathrm{V}$ instars. The first three instars of Eri silk worm were fed with chopped leaves IV and Vinstars of Eri silk worm were fed with mature leaves. The beds cleaning and spacing were done daily. Life cycle was recorded under all three conditions. The data was analyzed by using ANOVA. Means were separated utilizing the LSD.

\section{Result and Discussion}

Overall performance of Philosami aricini larvae kept in normal dark and light for 24 hours provided with same conditions of optimum temp. $25 \pm 2{ }^{\circ} \mathrm{C}$ and Relative humidity $75 \pm 5 \%$.(Table No.1) The larvae kept in dark condition expressed significantly better result than the in respect of light condition compare with control.

When B. mori. Entrained to a $12^{\text {th }}$ light/ $12^{\text {th }}$ dark schedule, the HIOMT like activity showed a significant diurnal variation with high levels during the dark period (Itohet al., 2004) Toheed et al., (2008). work on B. mori, they found that mean life cycle of B. mori was 62 days in dark and 68 days in light.

Table.1. Life cycle duration (days) of Philosamiaricini kept under Control, Dark and Light condition at $25 \pm 2^{\circ} \mathrm{C}$ and $75 \pm 5 \% \mathrm{RH}$

\begin{tabular}{|l|l|l|l|l|l|}
\hline Condition & Egg & Larva & Pupa & Adult & $\begin{array}{l}\text { Total Life } \\
\text { span }\end{array}$ \\
\hline Control & $12-15$ & $25-30$ & $15-20$ & $05-08$ & $57-73$ \\
\hline Dark (days) & $10-12$ & $20-25$ & $10-18$ & $05-06$ & $45-61$ \\
\hline Light (days) & $13-17$ & $28-32$ & $17-22$ & $06-09$ & $66-78$ \\
\hline
\end{tabular}


The diurnal variation in the activity persisted in constant darkness, but was suppressed by constant light. Hoffman and Subramanian (2005) reported that the role of light exposure on the final stages of development of Anopheles stephensi that there was a significant reduction in the development of adults mosquitoes when larvae were bred in the absence of light. Bratton (1990) reported that mayfly life cycle may be disrupted, while Crowson (1981) mentioned that the survival of glowworm is threatened by outdoor lighting. It was found that artificial life can affect mating of moths. (Anonymous, 1998). The total life span of Philosamia ricini in dark and light condition, with mean of 53 and 74respectively, were significantly different in compare to control 65(normal).

\section{Conclusion}

From the present study, it is concluded that Eri silk worm (Philosami aricini) shows shorter life cycle in dark condition then in light condition when kept under the same condition of temperature $25 \pm 2^{\circ} \mathrm{C}$ and $75 \pm 5 \%$ relative humidity.Further studies are needed to be done to investigate these and other life parameters at different temperature and relative condition with the feeding various natural and artificial diets.

\section{References}

Anonymous, 1990.Sericulture in Pakistan.Pakistan. J. Forestry. 4(2): 23-27.

Anonymous, 1998. Encarta Concise Encyclopedia Articles http://encarta.msn.com

Bratton J.H., 1990. A Review of the Scarcer Ephemeroptera and Plecoptera of Great Britian. Research and Survey in Nature Conservation NCC.
Choudhary S. N., 1982. Eri Silk industry. Published by Directorate of Sericulture and weaving Government of Assam. 16-25.

Crowson R.A., 1981. The biology of coleopteran, New York Press.

Fukuda T., 1960. Biochemical studies on formation of Silk protein. Part 9th. The direct and indirect Formation of the silk protein during growth of silkworm larva. Bullet Agric. Chemistry Society Japan. 24:396-401.

Hoffman S. and Subramanian G.M., 2005. Light Deprivation Affects Larval Development and Arresting Gene Expression in Anopheles stephensi. Journal of Medical Entomology, 42(5):801-804.

Ishfaq M. and Akram W., 1999. Reshumkaykerhun key Parwarish $(U r d u)$. 1st Edition. Pak Book Empire Publishing, Lahore.pp 11-12.

Itoh M.T., Nomura T. and Sumi Y., 2004. Hydroxyindole-Omethyltransferase activity in the silkworm bombyx mori Department of Chemistry , St. Marianna University School of Medicine, Sugao, Miyamae-ku , Kawasaki 216, japan.

Krishnaswami N.S., 1973 and Kumararaj. Manual of Sericulture, Vol. 2 silkworm rearing, F.A.O. United Nation, Rome, 121pp.

Mehmood, Ahmed and Gilani., 1987. Effect of Feeding Leaves of Morus alba and Morus leavigata on Larval Growth and Silk Yield of Silkworm, Bombyx mori , Pakistan J. Zool. 19 (3):239-243.

Savela M., 1998. http://www.funet.fi/pub/sci/bio/life

Toheed I., Mian I., Amna S. and Imtiaz A., 2008. Effect of light and dark exposure on the different Life parameters of silkworm, Bombyx mori $\quad$ L. Sarhad J. Agric Vol.24,No.1 